\title{
Foreign direct investment and income inequality in Latin America: a sectoral analysis
}

\author{
Macarena Suanes
}

ABSTRACT

This paper analyses the relationship between foreign direct investment (FDI) and income inequality in Latin America. In particular, it estimates the effect of FDI from a sectoral perspective, identifying three major sectors: the primary sector, manufacturing industry and services. Using a data panel for 13 economies in the 1980-2009 period, empirical evidence was found for a positive effect of FDI on income inequality in the service and manufacturing sectors. 


\section{I}

\section{Introduction}

Since the 1990s, Latin America has been a leading destination for foreign direct investment (FDI), according to data from the United Nations Conference on Trade and Development (UNCTAD, 2011). During the 1995-2009 period, FDI as a share of gross domestic product (GDP) was more than three times as great as it had been in the 1980s. This process has been accompanied in the region by substantial economic growth (especially in the fiveyear period from 2004 to 2009, when it averaged 5\% a year) and by great and persistent income inequality. The latter has become one of the main concerns of economic policymakers, owing both to its scale and to its persistence over time.

Although most of the literature dealing with the effects of FDI on economic growth points to it having had a positive effect on this in developing economies (De Mello, 1997 and 1999; Borensztein, De Gregorio and Lee, 1998; Li and Liu, 2005; Herzer, Klasen and Nowak-Lehmann, 2008; De Vita and Kyaw, 2009), the relationship between FDI and income inequality is not so obvious and has received less attention in the literature. Many studies estimating the relationship between FDI and income inequality have found it to be positive (Tsai, 1995; Velde, 2003; Choi, 2006; Basu and Guariglia, 2007; Herzer, Hühne and Nunnenkamp, 2012), while others have found it to be negative, or have been unable to find any relationship (Milanovic, 2003; Sylwester, 2005). At the microeconomic level, however, a large branch of the literature has found that when FDI is present, the wage gap between skilled and unskilled workers increases, as therefore does income inequality (Lipsey and Sjöholm, 2004; Mah, 2002; Velde, 2003; Aitken, Harrison and Lipsey, 1996; Feenstra and Hanson, 1997). Consequently, while there is no consensus, the empirical evidence does seem to point to income inequality being increased by FDI flows.

Another aspect that may prove relevant when it comes to analysing the effect of FDI on income inequality and that has received little attention in the literature is the effect the sectoral distribution of this investment may have. FDI tends to go to different economic sectors depending on the characteristics and attractions of each economy, examples being abundant cheap labour, plentiful natural resources and fiscal or institutional benefits. The hypothesis put forward in this study is that the channels through which FDI can affect inequality are connected to the sectors of the economy in which this investment is made in each country.

In fact, the sectoral distribution of FDI in the Latin American economies varies greatly by country. According to data from UNCTAD (2006), in 2006 manufacturing FDI accounted for an average of $26 \%$ of the regional total, being concentrated in more developed countries such as Argentina, Chile, Costa Rica and Mexico. In many other Latin American countries, the mining and oil sectors account for a large share of all FDI, this being the case with the Plurinational State of Bolivia, Chile and Colombia, where in 2006 these sectors accounted for between a third and a half of total FDI. Meanwhile, FDI in the agricultural sector is insignificant in most of the region's countries. Lastly, the service sector has taken on an increasing preponderance everywhere in recent years, accounting for $50 \%$ of total FDI in Latin America as a whole, with particular prominence for financial services, transport and telecommunications, and electricity, gas and water distribution.

Although there is no empirical evidence for the macroeconomic impact of FDI by sector on income inequality in developing economies generally, and the region in particular, there is evidence for the effect of FDI by sector on economic growth and productivity. Thus, Tondl and Fornero (2010) find evidence for a positive effect of FDI on productivity in all sectors of activity in the economies of Latin America, with this being greatest in the primary sector and financial services.

Against this background, the present article analyses and provides empirical evidence for the impact that FDI by sector is having on income inequality in the countries of Latin America. The dearth of literature studying the effect of FDI on income inequality in the region, together with the major trends seen there in the last decade (substantial economic growth, increased FDI flows and persistent income inequality), are the main reasons for this study, whose most innovative contribution is that it differentiates the effects of FDI by the sector in which it takes place.

To do so, it conducts two types of analyses. In the first, it considers the effect of FDI at the aggregate level 
on income inequality, while in the second it analyses this relationship separately for the main sectors of the economy that have been recipients of FDI (the primary sector, manufacturing and services).

Figure 1 illustrates the relationship between FDI as a share of GDP and income inequality (measured by the Gini coefficient) in the economies of Latin America, taking the averages of these variables for the 1980-2009 period. That there is a positive relationship between the two variables can be intuitively appreciated from this chart.

However, when the relationship between income inequality and FDI disaggregated by sector of activity is looked at, as in figure 2, the relationship is found to vary somewhat by sector. Thus, while there does seem to be a positive relationship in the primary and service sectors, there appears to be no clear relationship in the manufacturing sector.

The rest of this paper is organized as follows. Section II presents a brief review of the literature on the relationship between FDI and income inequality, with a particular emphasis on sectoral analysis. Section III describes the data and the main trends of the variables of interest in the region. Section IV lays out the empirical strategy, and section $\mathrm{V}$ discusses the results. Lastly, section VI presents conclusions.

FIGURE 1

Foreign direct investment (FDI) as a share of gross domestic product (GDP) and the Gini coefficient

(2008-2009 average)

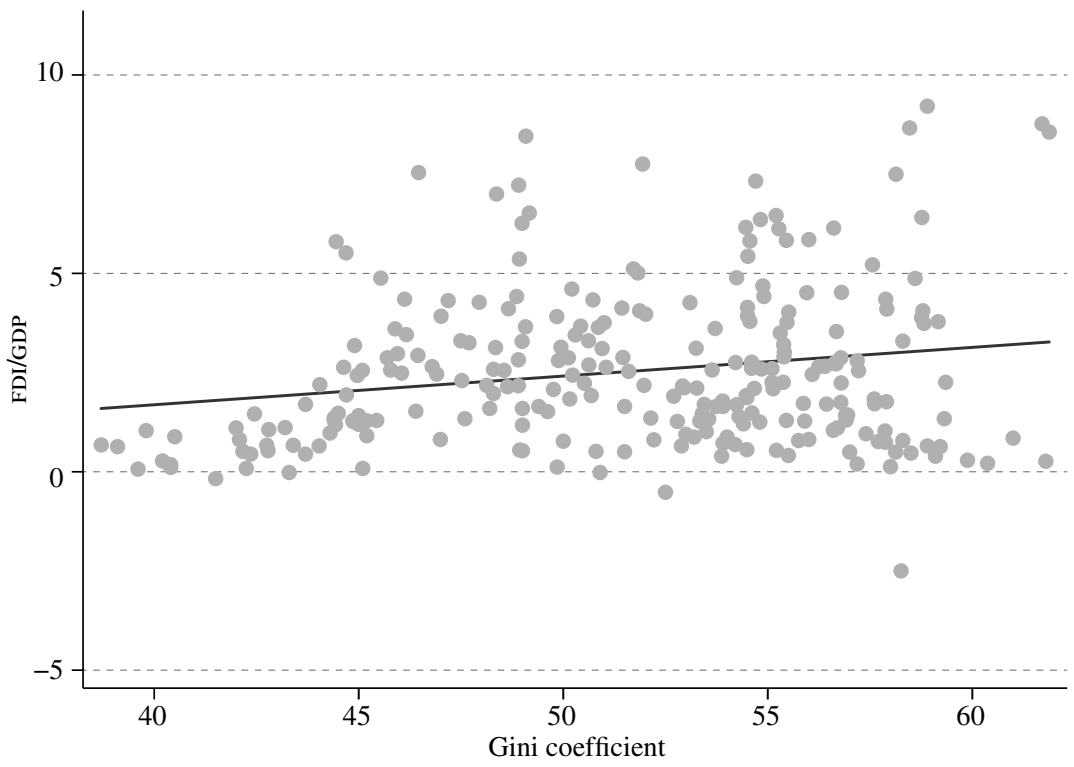

Source: Prepared by the author, on the basis of data from World Institute for Development Economics Research (UNU-WIDER), World Income Inequality Database, and World Bank, World Development Indicators. 
FIGURE 2

Gini coefficient and foreign direct investment (FDI) by sector of activity, 2008-2009 averages

(FDI as a share of sectoral gross domestic product (GDP))
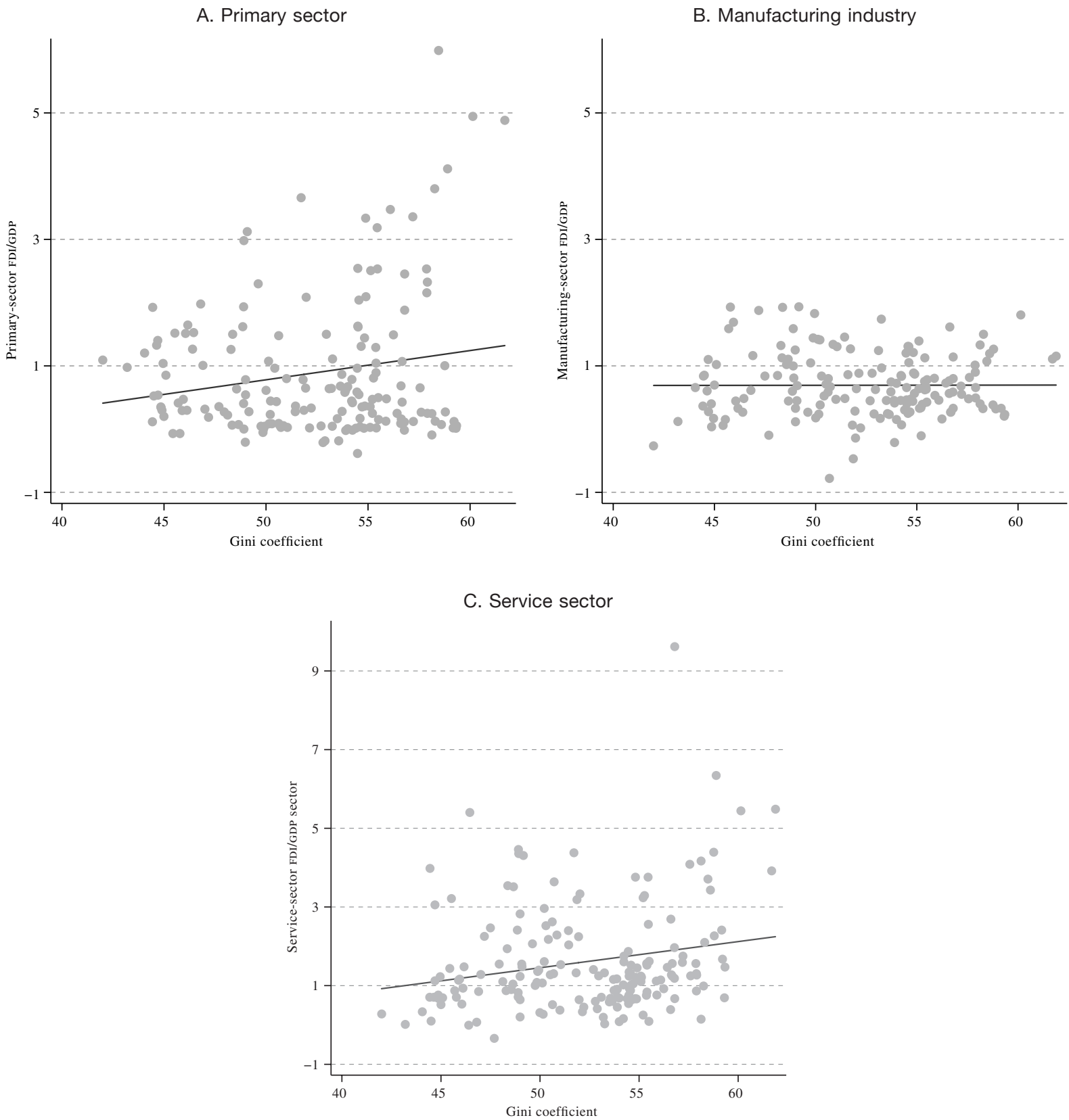

Source: Prepared by the author, on the basis of data from World Institute for Development Economics Research (UNU-WIDER), World Income Inequality Database. 


\section{II}

\section{Literature review}

This section presents a summary of both the theoretical and the empirical literature, focusing on the relationship between FDI and income inequality and on the effect of sectoral FDI on income inequality, identifying the main sectors of activity where this investment is found.

\section{Foreign direct investment (FDI) and income inequality}

The relationship between economic growth and FDI began to receive more attention in the literature during the 1990s because of the major trade liberalization process undergone by developing economies in that period. There is a degree of consensus in the empirical literature regarding the positive impact of FDI on economic growth in developing countries (De Mello, 1997 and 1999; Borensztein, De Gregorio and Lee, 1998; Li and Liu, 2005; Herzer, Klasen and Nowak-Lehmann, 2008; De Vita and Kyaw, 2009). Conversely, the effect of FDI on income inequality, particularly in developing economies, has received less attention, very probably because of data limitations and the dearth of literature studying possible theoretical links between the two variables.

The main contributions dealing with the possible channels whereby FDI might influence income inequality will now be detailed. Jensen and Rosas (2007) suggest two channels through which this investment might affect inequality. First, FDI brings capital into a country, thus reducing the total returns to capital and increasing the returns to labour. Foreign capital competes with local capital to capture domestic workers, raising wages and reducing the profitability of local firms. This effect would tend to reduce income inequality by narrowing the gap between wage rents and capital rents. The second way in which FDI might have an impact on inequality is that foreign firms tend to pay a wage premium for skilled workers in particular, widening the income gap between skilled and unskilled workers and thence increasing inequality. If these foreign firms also paid a wage premium to unskilled workers, FDI would tend to reduce income inequality by increasing the income of worse-off workers.

Velde (2003), drawing together other contributions, refers to three possible channels through which FDI may affect wage inequality in developing countries. First, he identifies a "composition effect" resulting from the fact that foreign firms tend to set up in sectors that are more intensive in skilled labour, thus improving the position of these workers relative to the unskilled (Feenstra and Hanson, 1997). Second, FDI can affect the supply of skilled workers via training and specific contributions to general education (knowledge transfer). Lastly, as advanced by Berman, Bound and Machin (1998), FDI can probably induce faster labour productivity growth both in foreign firms (technology transfer) and in local ones (secondary effects), and if productivity growth is skewed towards skilled sectors, then the gap between the sectors will grow. Velde (2003) uses a cross-section analysis for four economies of Latin America (Chile, Colombia, Costa Rica and the Plurinational State of Bolivia) in the 1978-2000 period and finds empirical evidence of FDI increasing wage inequality, and thence income inequality, in the region. Furthermore, a number of country studies support the hypothesis that FDI is associated with greater inequality in wage earnings, especially in developing economies. Some examples are Indonesia (Lipsey and Sjöholm, 2004), the Republic of Korea (Mah, 2002) and Mexico (Aitken, Harrison and Lipsey, 1996; Feenstra and Hanson, 1997), although it should be stressed that much of the empirical evidence also shows FDI to be associated with higher wages for workers of all kinds (Overseas Development Institute, 2002).

However, the empirical literature on the relationship between FDI and inequality at the macroeconomic level is not conclusive. Thus, Tsai (1995), using a crosssection analysis for 53 economies, estimates a positive and significant relationship between FDI and inequality, although when he uses dummy control variables (Latin America and Asia) he finds that this positive relationship could be capturing differences in inequality between economies rather than any role played by FDI. Choi (2006), using a panel of 119 countries in the 1993-2003 period, finds evidence that an increase in FDI increases inequality. A similar finding is indicated by the work of Basu and Guariglia (2007), who, using a panel of 119 developing economies for the 1970-1999 period, report a positive relationship between FDI, economic growth, income inequality and human capital. In a recent study, Herzer, Klasen and Nowak-Lehmann (2008) use 
cointegration techniques to analyse the impact of FDI on long-run income inequality for five economies of Latin America (Chile, Colombia, Mexico, the Plurinational State of Bolivia and Uruguay), showing that FDI has a significant and positive effect on income inequality in almost all these economies. By contrast, Milanovic (2003), employing household survey data for 129 countries from 1988, 1993 and 1998, finds FDI to have no effect on income distribution. Lastly, Sylwester (2005), using a panel of 29 developing economies for the 1970-1990 period, finds no evidence of a positive relationship between these variables. In summary, while the empirical evidence for the relationship between FDI and inequality in developing economies is not conclusive, in no case does it indicate that such investment has the effect of reducing inequality, but rather the opposite.

\section{Foreign direct investment (FDI) by sector and income inequality}

The literature studying the relationship between FDI and income inequality has paid little attention to an aspect that may be important for an understanding of the impact of FDI on developing economies, namely the effect of its sectoral composition. It seems reasonable to hypothesize that FDI will not have the same impact whatever sector of the economy receives it, but this is something that aggregate analysis cannot determine. Thus, the channels through which FDI affects inequality are likely to differ depending on which sector receives it.

The literature does identify some differential effects of FDI on income inequality by economic sector. The manufacturing sector is usually labour-intensive, and foreign firms investing in it in developing countries are usually seeking cheap labour and lower costs. Indeed, most theories about the distributive effects of FDI deal implicitly with investment in labour-intensive manufacturing. The conclusion they reach is that foreign investors reduce income inequality in economies with plentiful low-wage labour by increasing the demand for unskilled workers and paying higher wages than prevail in the domestic economy. According to this perspective, FDI should improve income distribution in recipient countries (Cornia, 2011). However, the empirical evidence is inconclusive and does not demonstrate this. For example, Velde and Morrissey (2004) found that FDI increased wages at all skill levels in four of the five East Asian countries analysed. In Mexico, conversely, the rise in wages in the presence of FDI was significantly smaller for unskilled workers than for skilled ones (Alarcón and McKinley, 1996).

On the other hand, FDI in the primary sector tends to exacerbate inequality, since ownership of natural resources is concentrated in a few hands and the rents from them are captured by those at the top of the distribution. Lastly, the service sector as a whole cannot be classified as labour- or capital-intensive, so the effects on inequality are not so obvious. To analyse the effects of capital flows in this sector, it is necessary to study its subsectors. For example, telecommunications are capital-intensive and employ skilled labour, while the tourism sector, for example, is more intensive in unskilled labour. Thus, FDI can be expected to increase inequality in the first case but reduce it in the second (Cornia, 2004).

Empirical macroeconomic studies do not usually identify the effect of FDI on inequality by economic sector. However, other branches of the literature do include disaggregation of FDI by sector in their analysis. For example, Aykut and Sayek (2007) find that the sectoral composition of FDI does matter when it comes to explaining productivity growth in developing countries and conclude that a large share for agriculture in the FDI total has a negative effect on growth in an economy, while a large share for manufacturing FDI has a positive effect. For their part, Nunnenkamp and Spatz (2004) find that aggregate growth is higher if a large share of a country's FDI is in the electrical machinery and equipment industry, rather than the food, chemical and metallurgical industries. Likewise, Tondl and Fornero (2010) identify FDI as having positive effects on productivity in all sectors of Latin American economies, although they may depend on specific conditions or be time-limited. The direct productivity effects are highest in the primary sector (agriculture, mining and oil production) and in financial services. 


\section{III}

\section{The data}

To estimate the impact of FDI on income inequality by sector, an unbalanced panel was constructed with data for the 1980-2009 period in 13 economies of Latin America. The countries included in the sample were Argentina, Brazil, Chile, Colombia, Costa Rica, the Dominican Republic, Ecuador, Honduras, Mexico, Paraguay, Peru, the Plurinational State of Bolivia and Uruguay. These countries were chosen because they had FDI data available by sector. Two analyses were conducted, one using annual and the other triennial data. This twofold approach was adopted because the use of annual data allowed the limited information available to be maximized, while triennial data were also included because no major changes were expected from one year to the next in some of the macroeconomic variables, such as inequality, and because this reduced short-term fluctuations and thence the influence of the business cycle, allowing attention to be focused on the long-term relationship.

The FDI measure used is the net inflow of foreign capital as a share of GDP. Aggregate data were obtained from the World Development Indicators database. As can be seen in figure 3, FDI more than trebled in the second subperiod analysed (1995-2009) relative to the previous period (1980-1994). This was due partly to the liberalization process initiated in the region in the early 1990s, which was also accompanied by major reforms and far-reaching privatization of public enterprises and services in a number of the region's countries, and partly to the sharp declines in interest rates between 2002 and 2008 , which encouraged investors in economies with a large amount of accumulated capital to go in search of more profitable investments, for example in Asia and Latin America. The economies receiving most FDI in the second period included Chile, the Plurinational State of Bolivia and Honduras, while Paraguay, Brazil and Uruguay had the lowest ratio of FDI to GDP. In absolute terms, however, Brazil and Mexico continued to be the economies that received by far the most FDI in millions of dollars (see table A.1 of the annex). When Latin America is compared to other regions, it is found, along with Asia, to be among the developing regions which received the greatest flows of FDI and where this investment grew most in the period analysed (see table A.2 of the annex).

FIGURE 3

Latin America (13 countries): foreign direct investment (FDI)

(Percentages of gross domestic product (GDP))

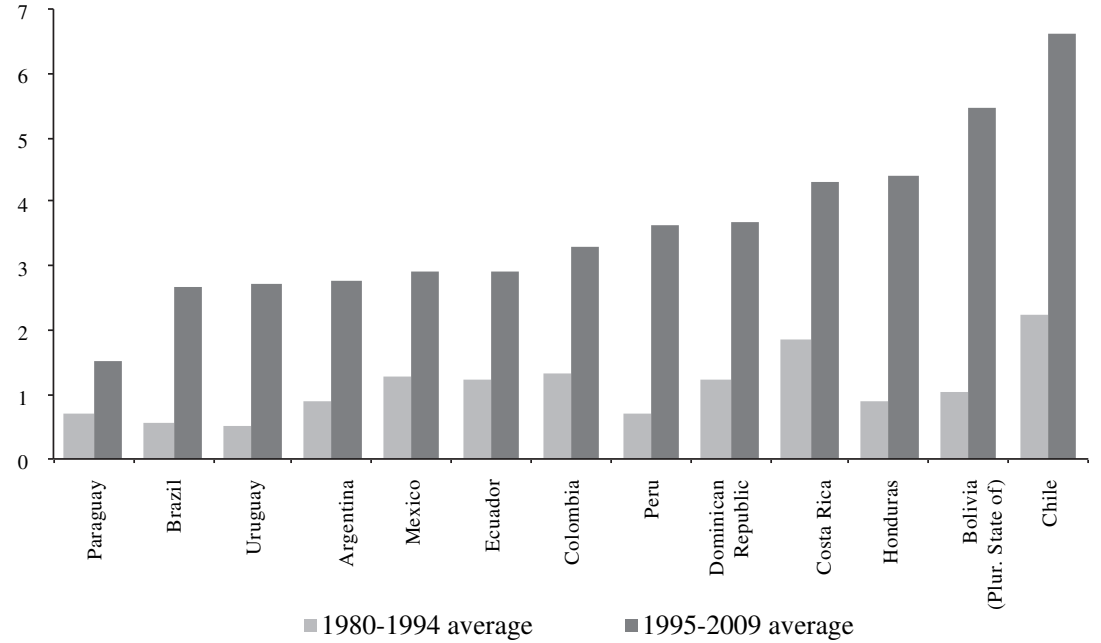

Source: Prepared by the author, on the basis of World Bank, World Development Indicators. 
Like aggregate FDI, sectoral FDI was calculated by taking net flows into each sector as a share of GDP. The data sources for sectoral FDI vary by country, as no institution has attempted to systematize an FDI data series by sectors of activity. ${ }^{1}$ In general, the sources used in this paper to prepare these data series were each country's central bank, institutes of statistics and, in some cases, institutes or organizations set up specifically to promote investment of this type (see table A.5 of the annex). Because the country information available was so heterogeneous, and with a view to preparing a data series that would be as homogeneous and comparable as possible, the decision was taken to group the data into three major sectors: the primary sector (including agriculture, mining and extractive industries), manufacturing industry and services.

As can be seen in figure 4, when averages for 19802009 are taken, the most important sector in explaining the evolution of FDI in the region is the service sector, which accounts for between $45 \%$ and $50 \%$ of total FDI flows into the region. The countries where servicesector FDI is particularly high as a share of total FDI

\footnotetext{
1 Since 2005, the Economic Commission for Latin America and the Caribbean (ECLAC) has presented some statistics by sectors of activity in its annual report on FDI in Latin America.
}

flows are Paraguay, the Dominican Republic, Uruguay, Honduras and Brazil. According to data from UNCTAD (2004), service-sector FDI quadrupled in developing economies between 1990 and 2002, while it doubled in the particular case of Latin America, mainly as a result of privatization and a new openness to foreign investment in telecommunications, public services and finance.

The income inequality indicator used was the Gini coefficient obtained from the World Income Inequality Database, ${ }^{2}$ which often reports more than one estimate of the Gini coefficient per country per year. Thus, with a view to using the most homogeneous and comparable data possible, the observations were selected, first, in the light of the quality classification prepared by the World Institute for Development Economics (UNU-WIDER), to eliminate lower-quality observations (ranking 4). ${ }^{3}$ Other controls were the income definition used (preference was given to disposable income), coverage by geographical area and population, and the source employed. For some countries, lastly, the inequality data were updated using the Socio-Economic Database for

\footnotetext{
2 World Income Inequality Database version 2.0c of May 2008, prepared by the World Institute for Development Economics Research (UNU-WIDER).

3 These observations are eliminated.
}

(Percentages of gross domestic product (GDP))

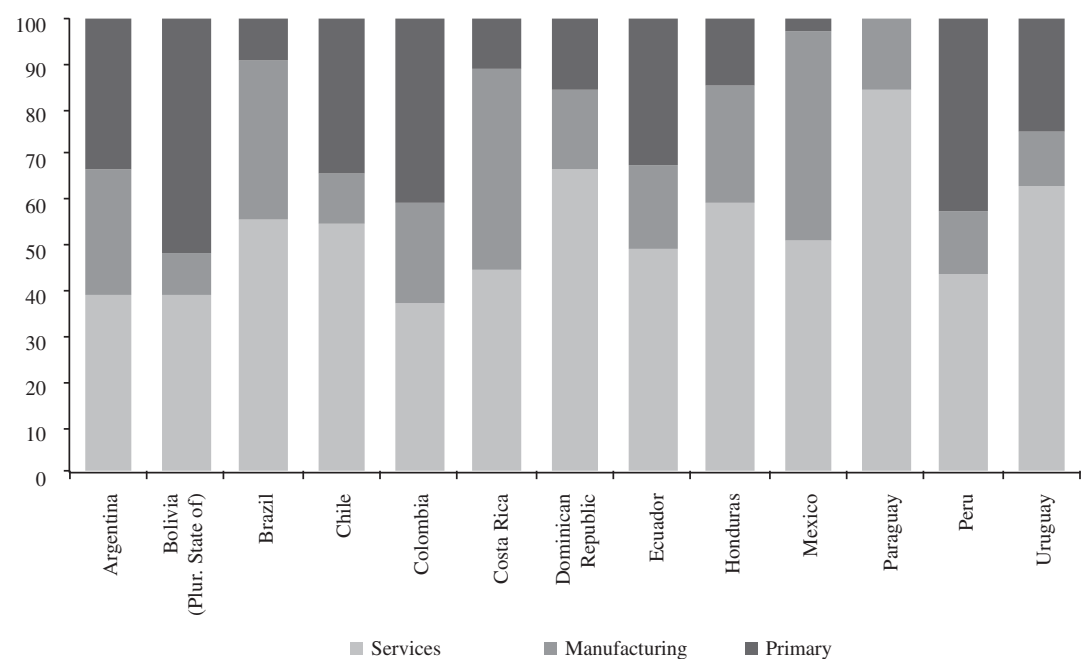

Source: Prepared by the author, on the basis of information from the respective countries. 
Latin America and the Caribbean (SEDLAC), ${ }^{4}$ maintaining the selection criterion mentioned above. Figure 5 presents the averages of the inequality coefficients by country for the two subperiods of the sample: 1980-1994 and 1995-2009.

Figure 5 reveals that Uruguay, Costa Rica and Argentina are in the group of countries that present lower

${ }^{4}$ See [online] http://sedlac.econo.unlp.edu.ar/. coefficients of inequality, while the Plurinational State of Bolivia, Brazil and Colombia present the highest index values. As regards evolution over time, while inequality tends to be highly persistent, Paraguay, Ecuador, Argentina and the Plurinational State of Bolivia experienced a significant increase during the period analysed, with Mexico, Brazil and Peru the only countries to present a significant reduction. This difference in evolution could be partly due to the implementation of specific policies in each countries.

FIGURE 5

\section{Latin America (13 countries): Gini coefficient by country}

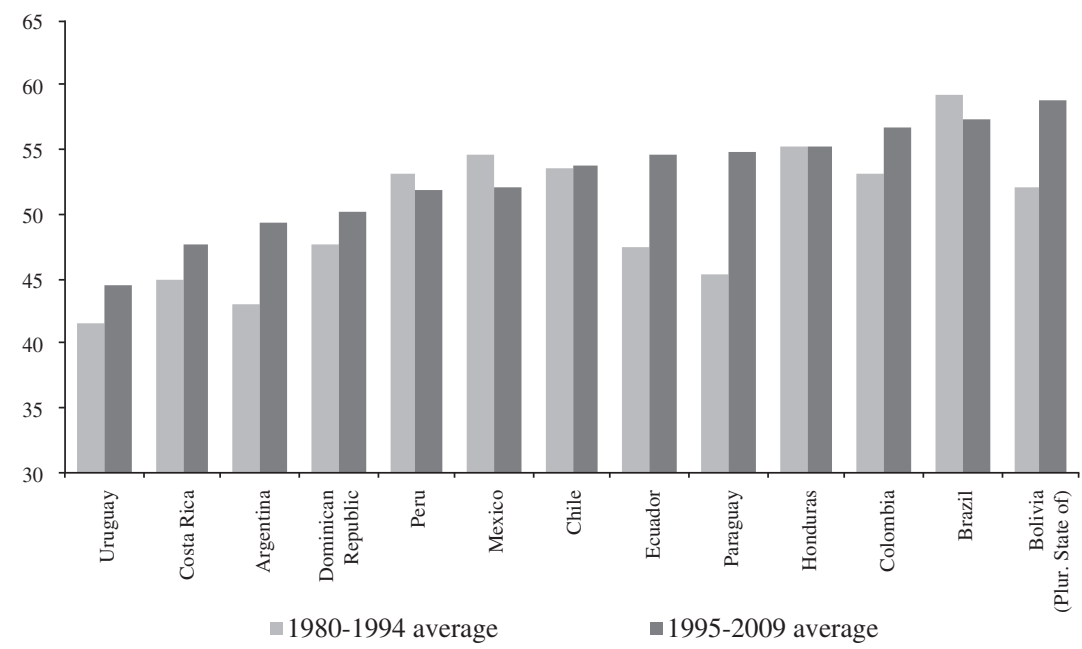

Source: Prepared by the author, on the basis of World Institute for Development Economics Research (UNU-WIDER), World Income Inequality Database, and the Socio-Economic Database for Latin America and the Caribbean (SEDLAC).

\section{IV}

\section{The empirical strategy}

In order to determine the effect of FDI on income inequality, and following the studies by Basu and Guariglia (2007), Choi (2006) and Tsai (1995), two equations were estimated, one with aggregate FDI data and one including FDI disaggregated by sectors of activity (primary, manufacturing and services). The purpose of conducting these two analyses was to find evidence as to whether FDI produced different effects on income inequality depending on the sector of activity it was in.

\section{The effect of FDI on income inequality}

The impact of FDI on income inequality in the aggregate is described in the following equation:

$$
\text { inequality }_{i t}=a_{0}+a_{1} F D I_{i t}+a_{2} X_{i t}+u_{i}+e_{i t}
$$

where the dependent variable is a measure of income inequality (the Gini coefficient) for country $i$ in period $t$, 
$F D I_{i t}$ is expressed as a percentage of GDP in country $i$ at time $t$, and $X_{i t}$ is a vector that includes the main control variables. The term $u_{i}$ represents fixed effects by country and $e_{i t}$ is the error term.

In accordance with the literature, the control variables that could affect either income inequality or FDI were introduced, as omitting them could result in biases in the estimation of the impact of FDI on income inequality. The control variables included are: trade as a share of GDP, human capital, population growth and public spending as a share of GDP.

In the first place, the data for the trade explanatory variable, which measures economies' external trade using the trade openness indicator (the sum of total imports and exports as a share of GDP), come from the World Development Indicators database. Traditional trade theory, such as the Heckscher-Ohlin model, suggests that as trade increases, wage inequality in developing countries, which tend to have a relative abundance of unskilled labour, tends to diminish. The more open an economy is to international trade, the more apparent the effect on wage inequality should be. However, the literature studying the relationship between FDI and inequality predicts the opposite effect, as it assumes that FDI will tend to go to sectors with more skilled workers, thereby increasing the wage gap between unskilled and skilled workers (Velde, 2003).

Second, the average number of years' secondary education was used as a proxy for the human capital variable. The data come from the database of Barro and Lee (2013). The literature on the relationship between inequality and human capital argues that a higher level of education in the population reduces income inequality (see, for example, Castelló and Doménech, 2002). In the third place, public spending is included on the basis that it is an important variable in the determination of income inequality and to control for the impact of fiscal policy on this inequality. According to the literature, higher public spending should be expected to result in a lessening of income inequality (Atkinson and Brandolini, 2006). Lastly, population growth is included to control for the size of economies. The descriptive statistics and the definitions and sources of the variables are presented in tables A.3 and A.4 of the annex.

Equation (1) was estimated with different specifications to test the robustness of the results. First, a fixed effects country model was estimated to control for the presence of unobservable heterogeneity between countries and the possible omission of relevant variables. The problem with models of this type is that they implicitly assume FDI to be strictly exogenous to inequality. This may be too great an assumption if FDI is correlated with other observable or unobservable variables affecting inequality and not controlled for in the model, or if FDI is a function of inequality rather than a determinant of it. Controlling for country fixed effects would deal with the latter problem, assuming that the correlation of FDI with the error term is fixed in time. In the second place, the equation was estimated using the two-stage least squares (TSLS) method with a view to controlling for the existence of endogeneity between the dependent variable and the explanatory variables. For the annual data, the lags of the variables themselves were used as instrumental variables, while in the case of the triennial variables, the variables at the start of the period were used as the instrument, as they were expected to be uncorrelated with the errors.

Lastly, the model was estimated using the firstdifference generalized method of moments (GMM) developed by Arellano and Bond (1991) and Arellano and Bover (1995). This technique provides a way of taking unobserved heterogeneity within the country into account while also controlling for the possible existence of endogeneity, using variables lagged by one or more periods as instrumental variables. To evaluate when the model was well specified, use was made of the Sargan test, which measures whether the model is properly specified and the instruments are valid, and the M1 and M2 tests, which measure the existence of serial correlation in the first- and second-order residuals, respectively (Arellano and Bond, 1991; Blundell and Bond, 1998).

\section{The effect of FDI by sector on inequality}

To investigate the relationship between sector-disaggregated FDI and income inequality, the following equation was estimated:

$$
\begin{gathered}
\text { inequality }_{i t}=a_{0}+a_{1} \text { IEDPrim }_{i t}+a_{2} \text { IEDind }_{i t} \\
+a_{3} \text { IEDServ }_{i t}+a_{4} X_{i t}+u_{i}+e_{i t}
\end{gathered}
$$

Once again, the dependent variable is a measure of income inequality for country $i$ in period $t$ (Gini coefficient); FDIprim ${ }_{i t}$ FDIind $_{i t}$ and FDIserv ${ }_{i t}$ represent FDI as a percentage of GDP in country $i$ at time $t$ in the primary, manufacturing industry and service sectors, respectively; $X_{i t}$ is a vector that includes the main control variables correlated with inequality; $u_{i}$ is country fixed effects; and $e_{i t}$ is the error term. 
To estimate equation (2), the same empirical strategy was used as for equation (1), and it was estimated under three different specifications: fixed effects, TSLS and the first-difference GMM. Just as with equation (1),

\section{V}

\section{Results}

This section presents the empirical results obtained for the panel of data from 13 economies of Latin America during the 1980-2009 period for the two analyses selected. First the results from the estimation of the effect of aggregate FDI on income inequality are presented, then the effect of FDI on this inequality by sector of activity is shown.

\section{Foreign direct investment (FDI) and income inequality}

Table 1 shows the main results from the estimation of the relationship between FDI and income inequality at the aggregate level. The different estimates in table 1 bear out the central hypothesis of this study: the relationship between FDI and income inequality in the Latin American economies is positive and significant in all the specifications considered (fixed effects, TSLS and GMM). These findings are in line with other studies in the literature (Tsai, 1995; Basu and Guariglia, 2007; Choi, 2006; Herzer, Hühne and Nunnenkamp, 2012). FDI can affect two components of income, capital or wages. A possible interpretation of the social effect derives from the effect on workers' wages; as noted by Velde (2003), one of the main causes of the greater inequality of the income generated by FDI in Latin America is that transnational firms tend to set up in sectors with highly skilled labour, and it is these that absorb most of the benefits of FDI, namely technology transfer, knowledge transfer and higher productivity. As a result, the wage gap between skilled and unskilled workers is found to widen, and thus income inequality to increase, in these economies. Column 1 of table 1 presents the results of the fixed effects estimation for the annual data. A change of one percentage unit in FDI for all the countries increases the Gini coefficient by 0.40 of a percentage point. This finding is particularly important when the stability of the Gini coeficient over time is considered. As mentioned in the previous section, the model was the strategy was replicated with the triennial data as a robustness method. The same control variables were used as in the first equation: trade, human capital, public spending and population growth. also estimated by TSLS using lags of the explanatory variables as instrumental variables in order to take account of the possible existence of endogeneity. The results presented in column 2 of table 1 confirm the positive and statistically significant relationship between FDI and income inequality. Lastly, the model was estimated dynamically by employing the first-difference GMM estimator (see column 3 of table 1). As in the previous specifications, FDI continues to present a positive sign and is significant. The order of magnitude of the FDI coefficient is fairly similar between the fixed effects and TSLS, while with the GMM estimator it is lower.

As regards the control variables, the public spending variable has a negative effect on inequality and is significant. This result is in line with the literature on the impact of fiscal policy on inequality, finding that higher public spending results in lower income inequality (Li, Xie and Zou, 2000; Afonso, Schuknecht and Tanzi, 2010; Muinelo-Gallo and Roca Sagalés, 2011 and 2013). Similarly, the human capital variable has a negative impact on income inequity, and this finding is robust under the different specifications. The literature shows that greater investment in human capital translates into a drop in income inequality, especially in developing economies (see Basu and Guariglia, 2007; Blomstrom and Kokko, 2003; Castelló and Doménech, 2002). This last finding is important, since education is highlighted by several studies as one of the most effective instruments for reducing poverty and inequality in developing economies, and should thus be treated as a relevant factor by public policymakers, especially when the policies concerned are redistributive in character.

As a robustness measure, the same models were estimated again, but using triennial data (see columns 4 , 5 and 6 of table 1). As can be appreciated, the results are similar to those obtained with annual data, since FDI has a positive sign and is statistically significant in all three specifications considered. In contrast with 
TABLE 1

Gini coefficient and foreign direct investment (FDI)

\begin{tabular}{|c|c|c|c|c|c|c|}
\hline \multirow{2}{*}{$\begin{array}{l}\text { Dependent variable: } \\
\text { Gini coefficient }\end{array}$} & \multicolumn{3}{|c|}{ Annual data } & \multicolumn{3}{|c|}{ Triennial data } \\
\hline & $\begin{array}{c}\text { Fixed effects } \\
\text { (1) }\end{array}$ & $\begin{array}{c}\text { TSLS } \\
(2)\end{array}$ & $\begin{array}{l}\text { First-difference } \\
\text { GMM (3) }\end{array}$ & $\begin{array}{c}\text { Fixed effects } \\
(4)\end{array}$ & $\begin{array}{c}\text { TSLS } \\
(5)\end{array}$ & $\begin{array}{c}\text { First-difference } \\
\text { GMM (6) }\end{array}$ \\
\hline FDI & $\begin{array}{l}0.403 * * * \\
(0.074)\end{array}$ & $\begin{array}{l}0.544 * * * \\
(0.113)\end{array}$ & $\begin{array}{c}0.199 * * \\
(0.096)\end{array}$ & $\begin{array}{l}0.464 * * * \\
(0.113)\end{array}$ & $\begin{array}{l}0.449 * * * \\
(0.115)\end{array}$ & $\begin{array}{l}0.405^{* * * *} \\
(0.075)\end{array}$ \\
\hline Trade & $\begin{array}{l}-0.002 \\
(0.012)\end{array}$ & $\begin{array}{l}-0.0003 \\
(0.017)\end{array}$ & $\begin{array}{l}-0.021 \\
(0.022)\end{array}$ & $\begin{array}{c}0.012 \\
(0.029)\end{array}$ & $\begin{array}{c}0.041 \\
(0.033)\end{array}$ & $\begin{array}{l}0.0236 \\
(0.034)\end{array}$ \\
\hline Population growth & $\begin{array}{l}-1.123 \\
(0.827)\end{array}$ & $\begin{array}{l}-1.201 \\
(0.922)\end{array}$ & $\begin{array}{l}-1.044 \\
(0.755)\end{array}$ & $\begin{array}{l}-1.787 * \\
(1.033)\end{array}$ & $\begin{array}{l}-0.654 \\
(0.947)\end{array}$ & $\begin{array}{l}2.299 \\
(1.997)\end{array}$ \\
\hline Public spending & $\begin{array}{l}-0.292 * * * \\
(0.083)\end{array}$ & $\begin{array}{l}-0.259 * * \\
(0.108)\end{array}$ & $\begin{array}{l}-0.133 \\
(0.175)\end{array}$ & $\begin{array}{l}-0.269 * \\
(0.165)\end{array}$ & $\begin{array}{l}-0.251 \\
(0.212)\end{array}$ & $\begin{array}{l}-0.403 \\
(0.348)\end{array}$ \\
\hline Human capital & $\begin{array}{l}-0.859 \\
(0.615)\end{array}$ & $\begin{array}{l}-1.599 * * \\
(0.823)\end{array}$ & $\begin{array}{l}-1.133 * * \\
(0.512)\end{array}$ & $\begin{array}{l}-2.088 * \\
(1.138)\end{array}$ & $\begin{array}{l}-1.896^{* * *} \\
(0.814)\end{array}$ & $\begin{array}{l}-1.843^{*} \\
(1.017)\end{array}$ \\
\hline Constant & $\begin{array}{l}56.765^{* * *} \\
(2536)\end{array}$ & $\begin{array}{l}57.617 * * * \\
(1718) \\
\end{array}$ & & $\begin{array}{l}59.007 * * * \\
(3562)\end{array}$ & $\begin{array}{l}54.979 * * * \\
\text { (3 269) }\end{array}$ & \\
\hline Sargan test ( $p$-value) & & & 0.520 & & & 0.124 \\
\hline M1 test ( $p$-value) & & & 0.000 & & & 0.003 \\
\hline M2 test ( $p$-value) & & & 0.625 & & & 0.181 \\
\hline Observations & 258 & 254 & 158 & 117 & 117 & 87 \\
\hline Adjusted $\mathrm{R}^{2}$ & 0.83 & 0.82 & & 0.82 & 0.81 & \\
\hline Countries & 13 & 13 & 13 & 13 & 13 & 13 \\
\hline
\end{tabular}

Source: Prepared by the author.

Note: All the estimations include the standard errors corrected for heteroskedasticity. The Sargan test is for overidentifying instruments in GMM models, and the M1 and M2 tests are for first- and second-order serial correlation in the residuals, respectively.

$* * *$ Significant at $1 \%$; ** significant at $5 \%$; $*$ significant at $10 \%$.

the previous case, when the TSLS estimator was used, the variables at the start of the period were selected as instrumental variables, on the basis that they would have little correlation with errors. The results for the control variables are also similar to those obtained with the annual data model. The most striking result is the one for the human capital variable, as it is the only robust finding in the three specifications and two samples, with a negative impact on inequality. Public spending and population growth present a negative sign and are statistically significant in the fixed effects estimation, but these findings are not so robust.

\section{FDI by sector and income inequality}

Table 2 shows the results of the estimation of the FDI effect by sectors of activity on income inequality in Latin America for the two samples and under the three specifications. As explained in the previous section, FDI was identified in three major sectors of activity: the primary sector, manufacturing industry and services.

As can be seen from table 2, FDI presents a positive sign and is statistically significant in both manufacturing and the service sector. Manufacturing presents the highest coefficient for the impact of FDI on inequality, although it is the service sector that displays the most robust estimates for the three specifications and two samples, with a coefficient similar to that for aggregate FDI, some 0.40 . This last finding is still more important for these economies if account is taken of trends over the last decade, with service-sector FDI more than doubling between 1990 and 2002, bringing this sector to the fore as the main recipient of such investment. ${ }^{5}$ The literature studying the effect of services in developing economies is inconclusive as regards the impact this sector can have on different aspects of the economy, while policymakers are not convinced that opening the doors to servicesector FDI would have positive effects (Banga, 2005). It is important to note that subsectors within this sector cannot be distinguished for all the countries, because of data limitations. This is a major constraint when it comes to capturing the effect of the service sector on the economy, particularly considering that the financial sector is one of the key subsectors accounting for the evolution of FDI in Latin America, especially since the 1990s.

\footnotetext{
${ }^{5}$ It has become an attractive destination, in particular, for FDI in the tourism, telecommunications and information technology subsectors (UNCTAD, 2004).
} 
TABLE 2

Gini coefficient and foreign direct investment (FDI) by sector

\begin{tabular}{|c|c|c|c|c|c|c|}
\hline \multirow{2}{*}{$\begin{array}{l}\text { Dependent variable: } \\
\text { Gini coefficient }\end{array}$} & \multicolumn{3}{|c|}{ Annual data } & \multicolumn{3}{|c|}{ Triennial data } \\
\hline & $\begin{array}{c}\text { Fixed effects } \\
\text { (1) }\end{array}$ & $\begin{array}{l}\text { TSLS } \\
(2)\end{array}$ & $\begin{array}{l}\text { First-difference } \\
\text { GMM (3) }\end{array}$ & $\begin{array}{l}\text { Fixed effects } \\
\text { (4) }\end{array}$ & $\begin{array}{l}\text { TSLS } \\
(5)\end{array}$ & $\begin{array}{l}\text { First-difference } \\
\text { GMM (6) }\end{array}$ \\
\hline \multirow[t]{2}{*}{ FDI_primary sector } & 0.194 & 0.171 & -0.049 & $0.492 * * *$ & $0.552 * * *$ & -0.143 \\
\hline & $(0.147)$ & $(0.135)$ & $(0.165)$ & $(0.166)$ & $(0.197)$ & $(0.249)$ \\
\hline \multirow[t]{2}{*}{ FDI_manufacturing sector } & $0.396^{*}$ & 0.422 & 0.341 & $0.901 * *$ & $2.197 * * *$ & $0.875 * *$ \\
\hline & $(0.243)$ & $(0.270)$ & $(0.363)$ & $(0.345)$ & $(0.719)$ & $(0.381)$ \\
\hline \multirow[t]{2}{*}{ FDI_service sector } & $0.408 * * *$ & $0.412 * * *$ & $0.198 * *$ & $0.437 * * *$ & $0.325 * * *$ & $0.468 * * *$ \\
\hline & $(0.078)$ & $(0.079)$ & $(0.090)$ & $(0.121)$ & $(0.084)$ & $(0.160)$ \\
\hline \multirow[t]{2}{*}{ Trade } & $0.039 * * *$ & $0.042 *$ & -0.012 & 0.036 & $0.057 *$ & 0.010 \\
\hline & $(0.015)$ & $(0.024)$ & $(0.035)$ & $(0.024)$ & $(0.033)$ & $(0.023)$ \\
\hline \multirow[t]{2}{*}{ Population growth } & 0.875 & 0.836 & -0.893 & -1.771 & $2.388 *$ & 0.199 \\
\hline & $(0.883)$ & (1.137) & $(0.928)$ & $(1.505)$ & $(1.439)$ & $(1.780)$ \\
\hline \multirow[t]{2}{*}{ Public spending } & $-0.362 * * *$ & $-0.313 * * *$ & -0.186 & $-0.327 *$ & -0.126 & -0.059 \\
\hline & $(0.120)$ & $(0.118)$ & $(0.197)$ & $(0.179)$ & $(0.204)$ & $(0.172)$ \\
\hline Human capital & $(0.756)$ & $(0.928)$ & $(0.566)$ & $(0.533)$ & $(0.466)$ & $(0.690)$ \\
\hline \multirow[t]{2}{*}{ Constant } & $55.626 * * *$ & $55.755 * * *$ & & $52.546 * * *$ & $75.684 * * *$ & \\
\hline & $(2903)$ & $(3455)$ & & $(4853)$ & $(2556)$ & \\
\hline Sargan test ( $p$-value) & & & 0.339 & & & 0.178 \\
\hline M1 test ( $p$-value) & & & 0.000 & & & 0.017 \\
\hline M2 test ( $p$-value) & & & 0.684 & & & 0.659 \\
\hline Observations & 171 & 170 & 121 & 74 & 68 & 57 \\
\hline Adjusted $\mathrm{R}^{2}$ & 0.87 & 0.87 & & 0.90 & 0.90 & \\
\hline Countries & 13 & 13 & 13 & 13 & 13 & 13 \\
\hline
\end{tabular}

Source: Prepared by the author.

Note: All the estimations include the standard errors corrected for heteroskedasticity. The Sargan test is for overidentifying instruments in GMM models, and the M1 and M2 tests are for first- and second-order serial correlation in the residuals, respectively.

$* * *$ Significant at $1 \%$;* significant at $5 \%$; significant at $10 \%$.

Public spending and human capital stand out among the control variables, being significant and of negative sign, in line with the main findings of the literature. Thus, both human capital investment and fiscal policy may be considered effective economic policy instruments for combating the persistent income inequality found in these regional economies. This last result is very robust both in the different specifications and at the two levels of analysis chosen, the aggregate one and the sectoral one. As for the trade variable, this is found to have a positive and statistically significant effect on inequality. This runs counter to the findings of traditional trade theory using the Heckscher-Ohlin model but is in line with the literature studying the effect of FDI on income inequality, which finds the opposite effect, i.e., an increase in income inequality when trade grows, as was explained in section II.
Finally, the results were tested for robustness by replicating the sectoral-level estimations with an alternative series of sectoral FDI data. Because the data sources for the aggregate FDI series and the sectoral FDI series are different, the totals present some differences too. In an effort to control for the possible effect of these, the sectoral data series were reconstructed in such a way that the sum of these would match the FDI total at the aggregate level. The results obtained with these new sectoral FDI series confirm that FDI in the manufacturing and service sectors increases income inequality, as the signs and significance of the variables are maintained under the three specifications taken and with the two samples used. ${ }^{6}$

\footnotetext{
${ }^{6}$ The results are not presented in the article but were used to control for the robustness of the findings.
} 


\section{VI}

\section{Conclusions}

This study uses an unbalanced panel of data for 13 economies to analyse the relationship between FDI and income inequality in Latin America. One of the main findings confirms that there is a positive relationship between FDI and income inequality, in line with a number of studies in the literature (Basu and Guariglia, 2007; Choi, 2006; Herzer, Hühne and Nunnenkamp, 2012; Velde, 2003; Tsai, 1995). Again, when the effect of FDI by sector of activity is analysed, the results show that FDI in both the service sector and manufacturing industry increases income inequality, which explains the previous finding. The positive effect of these sectors on the inequality variable is particularly salient because they are the sectors that have played the greatest part in the evolution of FDI over the last decade in the economies of the region studied, according to data from UNCTAD (2004).

Given the characteristics of the region's economies, most of which display persistent income inequality over time, these findings are very important from an economic policy perspective, since they provide empirical evidence for the distributive implications associated with FDI and thus open up an opportunity for governments to try to channel or guide external resources in such a way that FDI reaches the most disadvantaged sections of society, or at least to design and apply redistributive policies that enable the benefits from FDI to spread and enhance the welfare of the population.

In summary, this study is a contribution to the empirical literature, principally for the evidence it provides on the effect of sectoral FDI on income inequality in Latin America, showing that the sector FDI is implemented in matters from the point of view of its distributive effects. Thus, it highlights a differential impact depending on whether FDI is carried out in the service and manufacturing sector, or in the primary sector.

ANNEX

TABLE A.1

Latin America (13 countries): net inflows of foreign direct investment (FDI) (Millions of current dollars)

\begin{tabular}{|c|c|c|c|}
\hline & 1980-1994 average & 1995-2009 average & 1980-2009 average \\
\hline Paraguay & 42 & 120 & 89 \\
\hline Honduras & 31 & 433 & 240 \\
\hline Bolivia (Plurinational State of) & 55 & 485 & 282 \\
\hline Ecuador & 158 & 568 & 357 \\
\hline Uruguay & 56 & 651 & 413 \\
\hline Costa Rica & 121 & 864 & 524 \\
\hline Dominican Republic & 102 & 1118 & 649 \\
\hline Peru & 286 & 2912 & 1820 \\
\hline Colombia & 592 & 4687 & 2761 \\
\hline Chile & 723 & 6958 & 4224 \\
\hline Argentina & 1399 & 6968 & 4302 \\
\hline Mexico & 3190 & 19110 & 11626 \\
\hline Brazil & 1730 & 23863 & 14105 \\
\hline
\end{tabular}

Source: Prepared by the author, on the basis of World Bank, World Development Indicators. 
TABLE A. 2

Net inflows of foreign direct investment (FDI) by region, 1980-2009

(Millions of dollars and percentages)

\begin{tabular}{|c|c|c|c|c|c|c|}
\hline \multirow[b]{2}{*}{ Region } & \multicolumn{3}{|c|}{ FDI inflows in millions of dollars } & \multicolumn{3}{|c|}{ FDI as a share of the world total } \\
\hline & $\begin{array}{c}\text { Average } \\
1980-1994\end{array}$ & $\begin{array}{c}\text { Average } \\
1995-2009\end{array}$ & $\begin{array}{c}\text { Average } \\
1980-2009\end{array}$ & $\begin{array}{c}\text { Average } \\
1980-1994\end{array}$ & $\begin{array}{c}\text { Average } \\
1995-2009\end{array}$ & $\begin{array}{c}\text { Average } \\
1980-2009\end{array}$ \\
\hline Developed economies & 94579 & 646398 & 370488 & $73.0 \%$ & $65.7 \%$ & $66.5 \%$ \\
\hline Developing economies & 34454 & 306436 & 170445 & $26.6 \%$ & $31.1 \%$ & $30.6 \%$ \\
\hline Oceania & 176 & 663 & 420 & $0.1 \%$ & $0.1 \%$ & $0.1 \%$ \\
\hline Africa & 2915 & 23915 & 13415 & $2.3 \%$ & $2.4 \%$ & $2.4 \%$ \\
\hline Western Asia & 2533 & 28146 & 15339 & $2.0 \%$ & $2.9 \%$ & $2.8 \%$ \\
\hline South, East and South-East Asia ${ }^{a}$ & 8988 & 62188 & 35588 & $7 \%$ & $6 \%$ & $6 \%$ \\
\hline Latin America and the Caribbean & 9770 & 95553 & 52662 & $7.5 \%$ & $9.7 \%$ & $9.5 \%$ \\
\hline China & 10073 & 95971 & 53022 & $7.8 \%$ & $9.7 \%$ & $9.5 \%$ \\
\hline
\end{tabular}

Source: Prepared by the author, on the basis of data from the United Nations Conference on Trade and Development (UNCTAD).

a Excluding China.

TABLE A.3

\section{Descriptive statistics}

\begin{tabular}{|c|c|c|c|c|c|}
\hline Variable & & Mean & Standard deviation & Minimum & Maximum \\
\hline \multirow[t]{3}{*}{ Gini coefficient } & Overall & 51.63 & 5.340 & 38.70 & 61.88 \\
\hline & Between groups & & 4.340 & 43.23 & 58.02 \\
\hline & Within groups & & 2.883 & 41.15 & 58.50 \\
\hline \multirow[t]{3}{*}{ Foreign direct investment (FDI) } & Overall & 2.363 & 2.155 & -2.499 & 12.20 \\
\hline & Between groups & & 0.855 & 1.112 & 4.431 \\
\hline & Within groups & & 1.992 & -3.388 & 11.31 \\
\hline \multirow[t]{3}{*}{ Primary-sector FDI } & Overall & 0.861 & 1.099 & -1.858 & 6.295 \\
\hline & Between groups & & 0.710 & -0.0429 & 2.556 \\
\hline & Within groups & & 0.872 & -3.553 & 6.291 \\
\hline \multirow[t]{3}{*}{ Manufacturing-sector FDI } & Overall & 0.804 & 0.701 & -2.573 & 3.761 \\
\hline & Between groups & & 0.347 & -0.0539 & 1.359 \\
\hline & Within groups & & 0.625 & -1.716 & 3.842 \\
\hline \multirow[t]{2}{*}{ Service-sector FDI } & Overall & 1.691 & 1.528 & -0.482 & 9.132 \\
\hline & Within groups & & 1.393 & -1.439 & 8.491 \\
\hline \multirow[t]{3}{*}{ Human capital } & Overall & 1.936 & 0.585 & 0.708 & 3.658 \\
\hline & Between groups & & 0.451 & 1.181 & 2.869 \\
\hline & Within groups & & 0.392 & 1.023 & 2.835 \\
\hline \multirow[t]{3}{*}{ Population growth } & Overall & 1.789 & 0.630 & -0.151 & 3.133 \\
\hline & Between groups & & 0.539 & 0.482 & 2.503 \\
\hline & Within groups & & 0.358 & 0.962 & 2.551 \\
\hline \multirow[t]{3}{*}{ Trade } & Overall & 53.42 & 26.18 & 11.55 & 136.8 \\
\hline & Between groups & & 22.38 & 20.34 & 90.85 \\
\hline & Within groups & & 14.90 & -0.510 & 103.5 \\
\hline \multirow[t]{3}{*}{ Public spending } & Overall & 8.176 & 4.638 & 2.578 & 22.59 \\
\hline & Between groups & & 4.592 & 3.346 & 17.90 \\
\hline & Within groups & & 1.412 & 3.087 & 13.30 \\
\hline
\end{tabular}

Source: Prepared by the author, on the basis of data from World Bank, World Development Indicators; World Institute for Development Economics Research (UnU-WIDER), World Income Inequality Database; Penn World Tables; and R.J. Barro and J.W. Lee, "A new data set of educational attainment in the world, 1950-2010", Journal of Development Economics, vol. 104, Amsterdam, Elsevier, 2013. 
TABLE A.4

\section{Data sources}

\begin{tabular}{|c|c|c|}
\hline & Definition of variables & Sources \\
\hline Inequality & Gini coefficient & $\begin{array}{l}\text { World Income Inequality Database } \\
\text { version } 2.0 \mathrm{c}\end{array}$ \\
\hline Foreign direct investment (FDI) & Foreign direct investment as a percentage of GDP & World Development Indicators \\
\hline Human capital & $\begin{array}{l}\text { Share of the population with secondary education is } 25 \% \\
\text { or more of the total }\end{array}$ & Barro and Lee (2013) \\
\hline Public spending & Government spending as a percentage of GDP & Penn Table version 7.0 \\
\hline Population & Population growth rate & World Development Indicators \\
\hline Trade & Imports plus exports as a percentage of GDP & World Development Indicators \\
\hline
\end{tabular}

Source: Prepared by the author, on the basis of data from World Bank, World Development Indicators; World Institute for Development Economics Research (UNU-WIDER), World Income Inequality Database; Penn World Tables; and R.J. Barro and J.W. Lee, "A new data set of educational attainment in the world, 1950-2010", Journal of Development Economics, vol. 104, Amsterdam, Elsevier, 2013.

Note: GDP: Gross domestic product.

TABLE A.5

\section{Data sources (by country)}

\begin{tabular}{ll}
\hline Sectoral foreign direct investment (FDI) by country & Sources \\
\hline Argentina & National Institute of Statistics and Censuses (INDEC) \\
Bolivia (Plurinational State of) & International Accounts Office (DNI) \\
& National Institute of Statistics (INE) \\
Central Bank of Bolivia & Central Bank of Brazil \\
Chile & Foreign Investment Committee (CIE) \\
Colombia & Central Bank of Colombia \\
Costa Rica & Ministry of National Planning and Economic Policy \\
Ecuador & Central Bank of Ecuador \\
Honduras & Central Bank of Honduras \\
Mexico & Secretariat of Economic Affairs \\
Paraguay & Central Bank of Paraguay \\
Peru & Central Bank of Peru \\
Dominican Republic & Central Bank of the Dominican Republic \\
Uruguay & Central Bank of Uruguay \\
\hline
\end{tabular}

Source: Prepared by the author.

\section{Bibliography}

Aitken, B., A. Harrison and R.E. Lipsey (1996), "Wages and foreign ownership: a comparative study of Mexico, Venezuela, and the United States", Journal of International Economics, vol. 40, No. 3-4, Amsterdam, Elsevier.

Afonso, A., L. Schuknecht and V. Tanzi (2010), "Income distribution determinants and public spending efficiency", Journal of Economic Inequality, vol. 8, No. 3, Springer.

Alarcón, D. and T. McKinley (1996), "Increasing wage inequality accompanies trade liberalisation in Mexico", The Social Challenge of the New Economic Era in Latin America, A. Berry (ed.), Toronto, University of Toronto.

Arellano, M. and S. Bond (1991), "Some tests of specification for panel data: Monte Carlo evidence and an application to employment equations", Review of Economic Studies, vol. 58, No. 2, Oxford University Press.

Arellano, M. and O. Bover (1995), "Another look at the instrumental variable estimation of error-component models", Journal of Econometrics, vol. 68, No. 1, Amsterdam, Elsevier.
Atkinson, A. and A. Brandolini (2006), "The panel-of-countries approach to explaining income inequality: an interdisciplinary research agenda", Mobility and Inequality: Frontiers of Research in Sociology and Economics, S. Morgan, D. Grusky and G. Fields (eds.), Stanford, Stanford University Press.

Aykut, D. and S. Sayek (2007), "The role of sectoral composition of foreign direct investment on growth", Do Multinationals Feed Local Development and Growth?, L. Piscitello and G.D. Santangelo (eds.), Elsevier.

Banga, R. (2005), "Foreign direct investment in services: implications for developing countries", Asia-Pacific Trade and Investment Review, vol. 1, No. 2, Bangkok, United Nations.

Barro, R.J. and J.W. Lee (2013), "A new data set of educational attainment in the world, 1950-2010", Journal of Development Economics, vol. 104, Amsterdam, Elsevier.

Basu, P. and A. Guariglia (2007), "Foreign direct investment, inequality, and growth", Journal of Macroeconomics, vol. 29, No. 4, Amsterdam, Elsevier. 
Berman, E., J. Bound and S. Machin (1998), "Implications of skill-biased technological change: international evidence", The Quarterly Journal of Economics, vol. 113, No. 4, Oxford University Press.

Blomstrom, M. and A. Kokko (2003), "The economics of foreign direct investment incentives", NBER Working Paper, No. 9489, Cambridge, Massachusetts, National Bureau of Economic Research.

Blundell, R. and S. Bond (1998), "Initial conditions and moment restrictions in dynamic panel data models", Journal of Econometrics, vol. 87, No. 1, Amsterdam, Elsevier.

Borensztein, E., J. De Gregorio and J.W. Lee (1998), "How does foreign investment affect economic growth?", Journal of International Economics, vol. 45, No. 1, Amsterdam, Elsevier.

Castelló, A. and R. Doménech (2002), "Human capital inequality and economic growth: some new evidence", Economic Journal, vol. 112 , No. 478, Wiley.

Choi, C. (2006), "Does foreign direct investment affect domestic income inequality?", Applied Economics Letters, vol. 13, No. 12, Taylor \& Francis.

Clark. D. and others (2011), "FDI, technology spillovers, growth, and income inequality: a selective survey", Global Economy Journal, vol. 11, No. 2, De Gruyter.

Cornia, G.A. (2011), "Economic integration, inequality and growth: Latin America vs. the European economies in transition", Working Paper, No. 101, New York, Department of Economic and Social Affairs.

(2004), "Trade liberalization, foreign direct investment and income inequality", Understanding Globalization, Employment and Poverty Reduction, E. Lee and M. Vivarelli (eds.), London, Palgrave Macmillan.

De Mello, L. (1999), "Foreign direct investment-led growth: evidence from time series and panel data", Oxford Economic Papers, vol. 51, No. 1, Oxford University Press.

(1997), "Foreign direct investment in developing countries and growth: a selective survey", Journal of Development Studies, vol. 34, No. 1, Taylor \& Francis.

De Vita, G. and K.S. Kyaw (2009), "Growth effects of FDI and portfolio investment flows to developing countries: a disaggregated analysis by income levels", Applied Economics Letters, vol. 16, No. 3, Taylor \& Francis.

ECLAC (Economic Commission for Latin America and the Caribbean) (2010), Foreign Direct Investment in Latin America and the Caribbean 2009 (LC/G.2447-P), Santiago.

Feenstra, R. and G.H. Hanson (1997), "Foreign direct investment and relative wages: evidence from Mexico's maquiladoras", Journal of International Economics, vol. 42, No. 3-4, Amsterdam, Elsevier.

Herzer, D., S. Klasen and D.F. Nowak-Lehmann (2008), "In search of FDI-led growth in developing countries: the way forward", Economic Modelling, vol. 25, No. 5, Amsterdam, Elsevier.

Herzer, D., P. Hühne and P. Nunnenkamp (2012), "FDI and income inequality-evidence from Latin American economies", Working Paper, No. 1791, Kiel, Institute of World Economics.
Jensen, N.M. and G. Rosas (2007), "Foreign direct investment and income inequality in Mexico, 1990-2000", International Organization, vol. 61, No. 3, Cambridge, Massachusetts, The MIT Press.

Li, X. and X. Liu (2005), "Foreign direct investment and economic growth: an increasingly endogenous relationship", World Development, vol. 33, No. 3, Amsterdam, Elsevier.

Li, H., D. Xie and H. Zou (2000), "Dynamics of income distribution", Canadian Journal of Economics, vol. 33, No. 4, Canadian Economics Association.

Lipsey, R.E. and F. Sjöholm (2004), "Foreign direct investment, education and wages in Indonesian manufacturing", Journal of Development Economics, vol. 73, No. 1, Amsterdam, Elsevier.

Mah, J.S. (2002), "The impact of globalization on income distribution: the Korean experience", Applied Economics Letters, vol. 9, No. 15, Taylor \& Francis.

Milanovic, B. (2003), "Can we discern the effect of globalization on income distribution? Evidence for household budget surveys", Policy Research Working Paper, No. 2876, Washington, D.C., World Bank

Muinelo-Gallo, L. and O. Roca Sagalés (2013), "Joint determinants of fiscal policy, income inequality and economic growth", Economic Modelling, vol. 30, Amsterdam, Elsevier.

(2011), "Economic growth and inequality: the role of fiscal policy", Australian Economic Papers, vol. 50, No. 2-3, Wiley Blackwell.

Nunnenkamp, P. and J. Spatz (2004), "FDI and economic growth in developing countries: how relevant are host-country and industry characteristics?", Transnational Corporations, vol. 13, No. 3, Geneva, United Nations.

Overseas Development Institute (2002), "Foreign direct investment: who gains?", ODI Briefing Paper, London.

Sylwester, K. (2005), "Foreign direct investment, growth and income inequality in less developed countries", International Review of Applied Economics, vol. 19, No. 3, Taylor \& Francis.

Tondl, G. and J.A. Fornero (2010), "Sectoral productivity and spillover effects of FDI in Latin America", FIW Working Paper Series, No. 53.

Tsai, P.L. (1995), "Foreign direct investment and income inequality: further evidence", World Development, vol. 23, No. 3, Amsterdam, Elsevier.

UNCTAD (United Nations Conference on Trade and Development) (2011), World Investment Report 2009, New York, United Nations. (2006), World Investment Report 2006, New York, United Nations. (2004), World Investment Report 2004, New York, United Nations.

Velde, W.D. te (2003), "Foreign direct investment and income inequality in Latin America: experiences and policy implications", London, Overseas Development Institute, unpublished.

Velde, D.W. te and O. Morrissey (2004), "Foreign direct investment, skills and wage inequality in East Asia”, Journal of Asia and Pacific Economies, vol. 9, No. 3, Taylor \& Francis. 